attention to accuracy and to scientific discipline. He set himself the very highest standards of investigation and exposition. He applied the same conscientiousness to his numerous other duties; he served on the councils of the Geological Society, the Geologists' Association, the Mineralogical Society and the Institute of Mining and Metallurgy, being president of the last two; he was elected to a fellowship of the Royal Society in 1960, served on its council and became chairman of the British National Committee for Geology. He was a member of the Natural Environment Research Council and of the Iron and Steel Federation and the British Ceramic Research Association. During the past year he presided over the meetings of the International Sedimentological Congress at Reading and Edinburgh. All these, and his many other duties, he carried out with a zeal and an efficiency which were a constant source of amazement to all who knew him.

His public manner, apparently controlled and urbane, concealed a deeply shy and reserved nature. Despite this, however, all who were in contact with him immediately sensed a warmth of understanding. Unfailingly courteous, his time and energies were always at the service of his colleagues. He enjoyed the respect of all, and leaves a multitude of friends. J. E. Prentiof

\section{Dr P. J. du Toit}

DR P. J. DU ToIT, who died in Pretoria on November 13, 1967 , at the age of 79 , was one of South Africa's greatest men of science-first in the role of a brilliant young veterinary research worker, then as Dean of the Faculty of Veterinary Science at the Transvaal University College of South Africa, where he succeeded Sir Arnold Theiler in 1927, and later as Director of Veterinary Services in South Africa (1927-48), a responsibility which included guiding the destinies of the world-renowned Veterinary Research Institute at Onderstepoort.

While the careers of many lesser men may have ended there, at retirement, du Toit went on with characteristic enthusiasm and stamina to become the second President of the South African Council for Scientific and Industrial Research (CSIR) in 1951, succeeding Sir Basil Schonland. Later (1951-60) he was appointed President of the Scientific Council for Africa South of the Sahara (CSA)a non-governmental body that has since become a victim of political change in Africa. During these years, du Toit guided the activities of CSA at numerous meetings of the Commission for Technical Co-operation in Africa South of the Sahara (CCTA) held in East, Central, West and southern Africa.

Du Toit's academic qualifications included a BA (Hons.); PhD (with honours) from Zurich University; and a doctorate in veterinary science, with honours, from Berlin. He held six honorary doctorates at the time of his death, four from South African universities which recognized his outstanding contribution to science in Africa, and one each from the universities of Utrecht, Holland and Glasgow.

Du Toit was a Fellow of the Roval Society and belonged to twelve scientific societies all over the world. He served on many commissions, enquiring into education, veterinary science, agricultural science, medicine, museums and so on, and represented South Africa at many international conferences. He wrote more than 140 publications.

His early interest during the First World War, when he was allowed to continue his research in Germany despite the fact that he held a British passport, was leukaemia in cattle. He received a doctorate in veterinary science for this work from the University of Berlin and later collaborated with Professor P. Knuth on tropical veterinary problems. He was co-author with Knuth of a standard textbook (in German) on tropical diseases in domestic animals.

Du Toit returned to South Africa in 1919 to carry on with the fundamental research into lamsiekte (bovine botulism) begun by Sir Arnold Theiler. This was to have far-reaching results in the development of the study of mineral deficiencies. By 1928 he had focused his attention on protozoology and virus diseases as professor at the Transvaal University College of South Africa. A year before, he had visited Nigeria and reported on veterinary matters there at the request of the Colonial Office in the United Kingdom.

Despite growing administrative burdens, du Toit's research continued in earnest until after he retired as Director of Veterinary Services of the South African Department of Agriculture, and Dean of the Faculty of Veterinary Science, University of Pretoria, in 1948. A cross-section of his publications reveals interests ranging from rinderpest to iodine in the nutrition of sheep; from problems of immunity in animal diseases to studies of the mineral content and feeding value of natural pastures in South Africa.

It is difficult to write an appreciation of a scientist such as P.J. du Toit, for he would have been the first to contend that the praise was undeserved and his achievements were mainly due to the efforts of his colleagues. He will be remembered as an outstanding administrator with a mind comprehensive in its grasp of things and simple and precise in its setting out of a problem. In addition to his scientific and academic responsibilities he gave much time to public work of various kinds, including active membership of the South African Historical Monuments Commission.

As a personality, he will be remembered for his keen sense of humour and charming companionship. He was in great demand as a raconteur and after-dinner speaker, accomplishments which earned him the affectionate sobriquet "P. J.". He never flaunted his own achievements nor underrated the work of others. S. M. NAUDÉ

\section{Professor G. Z. Dimitroff}

Georae Z. Dimitroff, emeritus professor of astronomy at Dartmouth College, Hanover, New Hampshire, and former superintendent of the Harvard Observatory, died on January 1 at his home in Hartland, Vermont, at the age of 66. He had been a member of Dartmouth's astronomy department for twenty years before his retirement in June 1966.

A native of Svistove, Bulgaria, Dimitroff graduated from the University of Boston in 1927 and took his MA and $\mathrm{PhD}$ degrees at Harvard. He taught physics at Colorado State College and astronomy at Harvard and Radcliffe.

For five years before he went to Dartmouth, Dimitroff was superintendent of the Harvard Observatory where he helped to build some of the largest Schmidt cameras in existence before that at Mount Palomar was built. He advised the Mexican government about the building of their astrophysical observatory at Puebla, and was coauthor of a book on telescopes and accessories.

For hundreds of Dartmouth undergraduates Astronomy 1 and Professor Dimitroff were synonymous. In addition to this introductory course in stellar astronomy and the astronomical universe, popularly known as "stars", he also taught more advanced courses in astrophysics and observational astronomy. His open house "Evening with the Stars" at the Shattuck Observatory gave pleasure to many Hanoverians, young and old.

As a commander in the US Navy in the Second World War, Dimitroff undertook a variety of scientific missions in Europe and Japan, including studies of optical developments there. On leave from Dartmouth in 1956, he surveyed astronomical developments in Europe and the Middle East, and at that time was scientific liaison officer with the US embassy in London. He went to Russia in 1958 as a member of the International Astronomical Union and returned there in 1963 as part of a world tour of observatories. Impressed with Russian scientific advances, he predicted that in twenty years Russia would be the leading scientific nation. 